\title{
A CASE OF RECURRENT MISCARRIAGES WITH ANAEMIA
}

\section{General Medicine}

Dr. Kolluru V D Post Graduate, Dept OfGeneral Medicine Guntur Medical College, Guntur.

Karthik*

*Corresponding Author

\section{Dr. Valeti}

Rajeswari

Post Graduate, Dept Of General Medicine Guntur Medical College, Guntur.

\section{ABSTRACT}

APLAS/APS is an auto antibody mediated acquired thrombophilia with recurrent arterial / venous thrombosis and pregnancy morbidity . It primarily affects females .5 cases per 1,00,000 population Diagnosis of APLAS should be considered in cases of thrombosis, CVA in individuals less than $55 \mathrm{yrs}$ of age. We report a case of a $21 \mathrm{yr}$ old female who had history of jaundice (on and off episodes) excessive menstrual bleeding with past history of 3 miscarriages. She was screened and evaluated for Autoimmune diseases and found to have ANTIPHOSPHOLIPID ANTIBODY SYNDROME. She was kept on anticoagulants and aspirin. And patient was doing well on follow up. Any miscarriages/ anaemia in young females needs active investigation so that appropriate treatment can be started to halt the disease process.

\section{KEYWORDS}

\section{BACKGROUND}

APLAS/ APS is an auto antibody mediated acquired thrombophilia with recurrent arterial/venous thrombosis and pregnancy morbidity.It primarily affects females .5 cases per $1,00,000$ population

Diagnosis of APLAS should be considered in cases of thrombosis, CVA in individuals less than $55 \mathrm{yrs}$ of age.

The diagnosis of APLAS include clinical and laboratory criteria.

The presence of at-least one clinical and one laboratory criterion is compatible with diagnosis.

Anti cardiolipin antibodies, Lupus anticoagulant and Anti B2 GP1 antibodies can be positive among APLAS positive individuals. ( LAB CRITERIA) Two occasions 12 weeks apart

Vascular thrombosis or Pregnancy morbidity ( CLINICAL CRITERIA)

\section{CASE REPORT}

A 21 year old female by name Supriya, resident of Guntur district presented to OPD with history of Menorrhagia, one month back which lasted for a duration of 6 days associated with yellowish discolouration of eyes and urine. She was admitted at a nursing home and treated for 5 days. History of 1 unit of packed cell transfusion was done in view of anaemia ( haemoglobin 3.8gm\%)

(2017) She had history of yellowish discolouration of eyes and urine 3 years back for which she was admitted at a local hospital and treated for 1 week. Later the jaundice subsided.

(2018- JUNE) She got married one year later, conceived 2 months after the marriage. At the end of 4th month of pregnancy she had excess bleeding per vagina for which she consulted a gynaecologist when she came to know that her pregnancy was aborted. She Used medications for control of bleeding per vagina and expulsion of remaining fetal products

Few months later she conceived again. At the end of 7th month, she had loss of amniotic fluid for which she went to a gynaecologist. They said that she had a dead fetus and advised to use medications to prevent infections to mother.

(2019- October ) Few days after this miscarriage, she had history of jaundice associated with fever for which she was investigated to have dengue fever. Got admitted in nursing home and treated for 1 week.

(2020)Few months later, she conceived for the third time. Again she had miscarriage at the $3 \mathrm{rd}$ month of gestational period. Few days later patient had the present complaints of jaundice with bleeding per vagina for 6 days .

On examination She had pallor, icterus and mild splenomegaly.
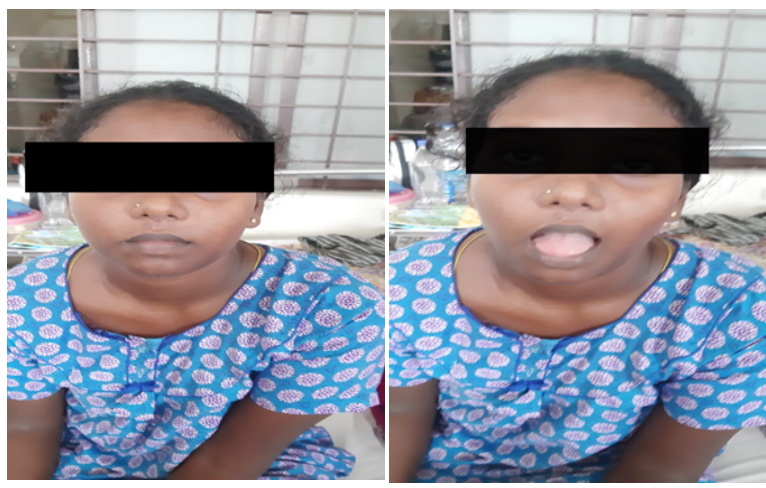

Laboratory investigations :-

CBC

HEMOGLOBIN $7 \mathrm{gm} \%$

TRBC 2.3

TWBC 8000 Polymorphs 65\% Lymphocytes 30\% Monocytes 3\% eosinophils $2 \%$

ESR 20

PLATELET COUNT 2,80,000

PCV $21 \%$

Peripheral smear shows :-

RBCs Microcytic hypochromia with ovalocytes, tear drop cells , polychromatophils and target cells

\section{WBCs normal}

Platelets adequate

Impression Microcytic hypo-chromic anaemia , advised haemolytic workup.

Coombs direct test POSITIVE

Coombs indirect test NEGATIVE

Serum Beta 2 glycoprotein 1 antibodies 62 units $/ \mathrm{mL}$ ANTICARDIOLIPIN IgMANTIBODIES 26 (positive) ANTICARDIOLIPIN IgG ANTIBODIES 64 (positive) LUPUS ANTICOAGULANT SCREEN 68 seconds CONTROL 31 seconds

\section{LAC SCREEN/CONTROL RATIO 2}

Serum HAPTOGLOBIN levels $32.5 \mathrm{mg} / \mathrm{dl}$

Serum VITAMIN b $12166 \mathrm{pg} / \mathrm{ml}$ 
Serum folate $2.84 \mathrm{ng} / \mathrm{ml}$

Serum LH $1.72 \mathrm{mIU} / \mathrm{ml}$

FSH $3.84 \mathrm{mIU} / \mathrm{ml}$

PROLACTIN $10.74 \mathrm{ng} / \mathrm{ml}$

\section{THYROID PROFILE -}

T3 $1.27 \mathrm{ng} / \mathrm{ml}$

$\mathrm{T} 410.24 \mathrm{ug} / \mathrm{dl}$

$\mathrm{TSH} 1.80 \mathrm{uIU} / \mathrm{ml}$

\section{LIVER FUNCTION TESTS}

Serum BILIRUBIN $3.9 \mathrm{mg} / \mathrm{dl}$

Indirect $2.8 \mathrm{mg} / \mathrm{dl}$

Direct $1.1 \mathrm{mg} / \mathrm{dl}$

SGOT $26 \mathrm{IU} / 1$

SGPT 33 IU/1

ALBUMIN $4.1 \mathrm{mg} / \mathrm{dl}$

GLOBULIN $2.5 \mathrm{mg} / \mathrm{dl}$

ALP 81 IU/L

Serum LDH 552 U/L

ANALEVELS 1.24

ANAPROFILE-NEGATIVE

\section{ULTRASOUND SHOWS :-}

SPLENOMEGALY

RIGHT FOLLICULAR OVARIAN CYST NOTED.

\section{DISCUSSION :}

Patient was advised follow up to OPD regularly . Entire investigation profile was repeated again.

\section{Patient was diagnosed to have ANTIPHOSPHOLIPID ANTIBODY SYNDROME (APLAS)}

CAPS ( catastrophic aplas ) is a life threatening rapidly progressive thromboembolic disease involving simultaneously 3 or more organs .

One third of the patients with SLE or other autoimmune diseases posses these antibodies with only $5-10 \%$ developing APLAS .

Clinical manifestations represents the consequences of arterial or venous thrombosis.

Pregnancy morbidity manifests with increased risk of recurrent miscarriages, IUGR, preeclampsia, eclampsia and preterm birth .

Major causes of these complications are due to INFARCTIONS OF THE PLACENTA.

Treatment options include aspirin 80mg, Low molecular weight heparin, warfarin, rivaroxaban, fondaparinux and IV immunoglobulins .

\section{CONCLUSION}

Young females with history of recurrent abortions and history of jaundice associated with anaemia needs to be evaluated for Autoimmune diseases and screened for APLAS to prevent further abortions.

ACKNOWLEDGEMENTS: NIL

CONFLICTS OF INTEREST: NIL

\section{REFERENCES}

OXFORD textbook of rheumatology

Harrison's principles of internal medicine, 20th edition

CDT Rheumatology.

4. Evans, NS, Ratchford, EV. Vascular Disease Patient Information Page: Venous Thromboembolism (deep vein thrombosis and pulmonary embolism). Vasc Med 2014; 19: 148-150.

5. Petri, M. Epidemiology of the antiphospholipid antibody syndrome. J Autoimmun2000; 15: $145-151$ 